\title{
Springtime transport and retention of Calanus finmarchicus in Massachusetts and Cape Cod Bays, USA, and implications for right whale foraging
}

\author{
Mingshun Jiang ${ }^{1, *}$, Moira W. Brown ${ }^{2}$, Jefferson T. Turner ${ }^{3}$, Robert D. Kenney ${ }^{4}$, \\ Charles A. Mayo ${ }^{5}$, Zibiao Zhang ${ }^{1}$, Meng Zhou ${ }^{1}$ \\ ${ }^{1}$ Department of Environmental, Earth, and Ocean Sciences, University of Massachusetts Boston, 100 Morrissey Blvd., Boston, \\ Massachusetts 02125, USA \\ ${ }^{2}$ New England Aquarium, Central Wharf, Boston, Massachusetts 02110, USA \\ ${ }^{3}$ Biology Department and School for Marine Science and Technology, University of Massachusetts Dartmouth, \\ North Dartmouth, Massachusetts 02747, USA \\ ${ }^{4}$ Graduate School of Oceanography, University of Rhode Island, Narragansett, Rhode Island 02882, USA \\ ${ }^{5}$ Provincetown Center for Coastal Studies, 115 Bradford Street, Provincetown, Massachusetts 02657, USA
}

\begin{abstract}
The Massachusetts Bay (MB) and Cape Cod Bay (CCB) system is a unique coastal embayment, with CCB serving as a high-use feeding ground for endangered North Atlantic right whales Eubalaena glacialis during winter and early spring. We used a hydrodynamic model, observed Calanus finmarchicus (the preferred prey of right whales) abundance, and right whale sightings during 1997-2004 to examine the transport and retention of $C$. finmarchicus in MB-CCB and the implications for right whale activity. A particle-tracking program was embedded into the model to simulate the Lagrangian residual circulation, and the transport and retention of passive particles. The results indicate significant correlations in the inter-annual variability of coastal transport, circulation pattern, C. finmarchicus abundance, and right whale sightings in spring. In normal years (with prevailing northwesterly winds), the monthly mean distributions of particles and Lagrangian residual currents show a coherent pattern with 2 particle retention areas in central $\mathrm{CCB}$ and central $\mathrm{MB}$, respectively. The CCB retention area closely matches the area of high probability of right whale occurrence and feeding activity, indicating that this is an area favorable to zooplankton aggregations. In other years (e.g. 2002), the coastal current is significantly reduced due to prevailing southwesterly winds, and the particle retention zone is shifted northward, coincident with low $C$. finmarchicus abundance and whale sightings in CCB. The study also suggests that the North Atlantic Oscillation may influence $C$. finmarchicus abundance and distributions, and hence, right whale feeding activity in CCB through surface winds affecting MB-CCB circulation, and hence, zooplankton distributions.
\end{abstract}

KEY WORDS: Numerical model · Circulation · Calanus finmarchicus $\cdot$ Right whale $\cdot$ Retention · Massachusetts Bay · Cape Cod Bay · North Atlantic Oscillation

\section{INTRODUCTION}

The Massachusetts Bay (MB) and Cape Cod Bay (CCB) system is a semi-enclosed embayment located in the southwestern Gulf of Maine (GOM) (Fig. 1). Along its eastern boundary, MB is open to the GOM, with water exchange mainly through the North and South Passages. South of MB, CCB is shallower and has no direct water exchanges with the GOM.

$\mathrm{CCB}$ is a unique shallow embayment serving as a high-use feeding ground for the endangered North Atlantic right whale Eubalaena glacialis (Winn et al. 

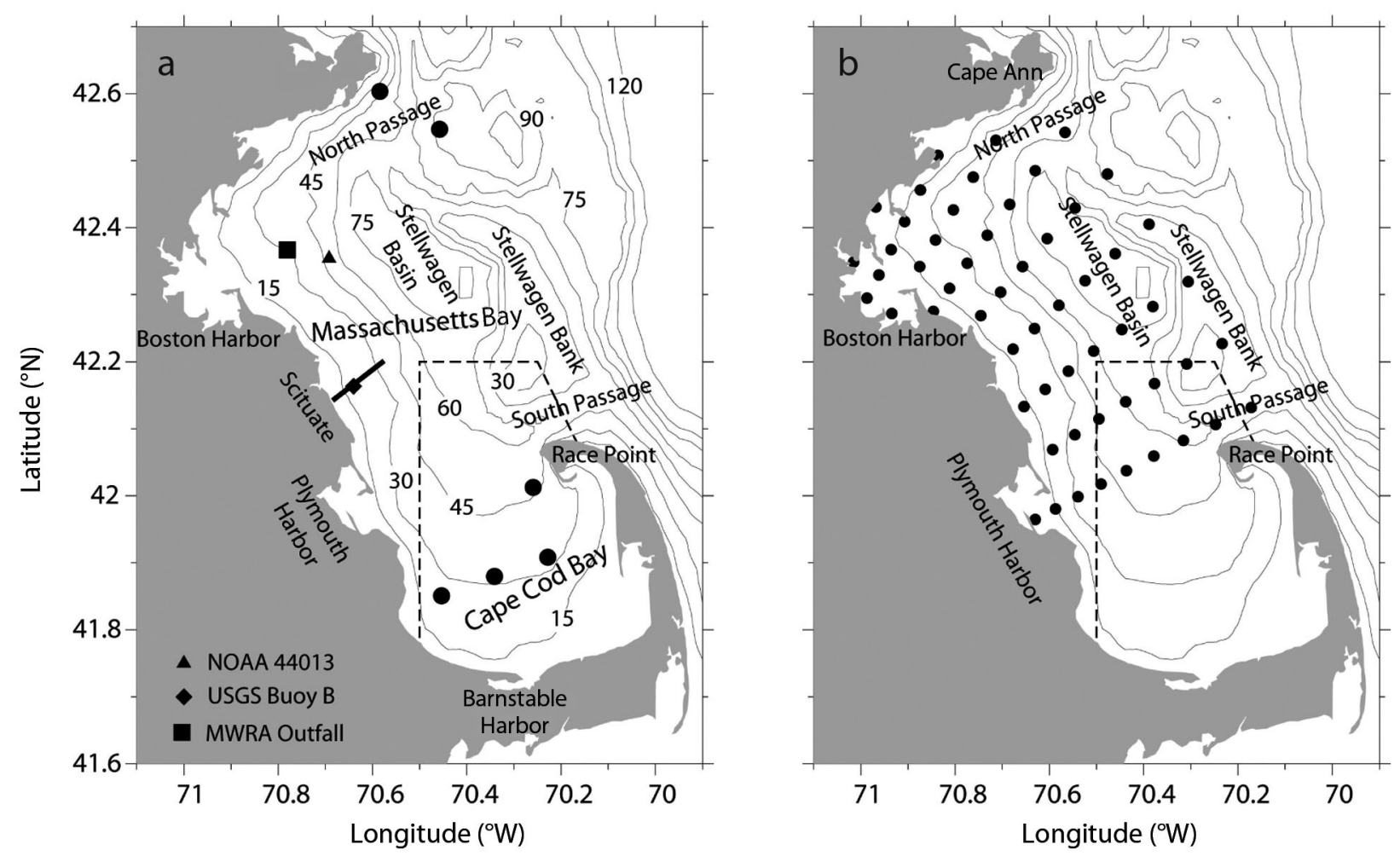

Fig. 1. (a) Bathymetry of Massachusetts Bay (MB) and Cape Cod Bay (CCB). Black dots indicate the zooplankton sampling stations in CCB and the North Passage. The solid line indicates the segment for calculating the transport of coastal current. The dashed line indicates the border of the right whale critical habitat in CCB. (b) Release locations of passive particles for simulations in 2000-2003. At each location, one particle was released at each of the 6 selected sigma layers. Note that the model domain is bigger (see Fig. 2)

1986, Mayo et al. 2004). The annual presence of right whales in CCB generally starts in late winter, peaks in March and April, and ends in May. However, the feeding activity of right whales in $\mathrm{CCB}$ shows significant inter-annual variability. For example, extremely low right whale sightings were reported in spring 2002 (Mayo et al. 2004). Dramatic inter-annual variability in total sightings and in the peak period of sightings in other feeding grounds also has been documented (Kenney et al. 1995, Baumgartner et al. 2003). The principal prey of right whales is calanoid copepods, especially Calanus finmarchicus, and right whales almost exclusively exploit dense aggregations of the older stages of C. finmarchicus (Murison \& Gaskin 1989, Mayo \& Marx 1990, Kenney et al. 1995, 2001, Baumgartner \& Mate 2003, Baumgartner et al. 2003). Therefore, changes in right whale presence are likely related to changes in $C$. finmarchicus abundance and the conditions for $C$. finmarchicus distribution and aggregation.

Circulation may play an important role in the abundance and distribution of Calanus finmarchicus in the MB-CCB system. In spring, surface circulation in the $\mathrm{MB}-\mathrm{CCB}$ system is controlled by an intruding branch of the Western Maine Coastal Current (WMCC), a baroclinic density gradient caused by freshwater runoff and local surface wind forcing. The general circulation pattern is counter-clockwise, with the coastal current flowing along the western coast of $\mathrm{MB}$ and penetrating deeply into CCB (Bigelow 1927, Geyer et al. 1992, Jiang \& Zhou 2004). This coastal current transports nutrients, organic matter, and biota (including zooplankton) from the GOM into MB-CCB and provides the only external source of zooplankton to CCB. This source is especially critical to C. finmarchicus in CCB since, as a cold temperate species, the C. finmarchicus population in CCB has to be renewed every spring. The upstream source of $C$. finmarchicus in $\mathrm{MB}-\mathrm{CCB}$ is likely from the re-emergence of overwintering $C$. finmarchicus in the GOM. In CCB, currents are normally weak, favoring accumulation of particles such as phytoplankton, organic matter and zooplankton (Jiang et al. 2007a).

The ultimate controls of long-term horizontal transport and accumulation of passive particles such as zooplankton are the Lagrangian residual currents, which are defined as the residual displacements of particles over a certain period, such as $\mathrm{M}_{2}$ tide (Zimmerman 
1981, Ottino 1989). Lagrangian residual currents have 2 components: (1) Eulerian residual currents representing the temporal mean currents at fixed locations and (2) Stokes drifts arising from the spatial gradients of currents, which are mainly due to the interactions between tides, surface winds and bottom topography (Longuet-Higgins 1969). The Lagrangian residual currents in the GOM region have been calculated by Loder et al. (1997) using a finite-element model. However, no results were presented for the MB-CCB system as their model grid was too coarse.

Zooplankton abundances and aggregations are also strongly affected by their local growth, predation, and behaviors, such as diel vertical migration, predator avoidance and mate seeking (see Folt \& Burns 1999 and the references therein). Interactions of biological and physical processes would create many complicated scenarios in the formation of zooplankton patches (Franks 1992, Folt \& Burns 1999).

Previous studies have suggested a complex correlation between zooplankton abundance in the GOM region and large-scale variability associated with the North Atlantic Oscillation (NAO), possibly with some time lag (e.g. Conversi et al. 2001, Greene \& Pershing 2000, Greene et al. 2003). Hydrology, nutrients and phytoplankton in the GOM are also subject to largescale influences (Petrie \& Drinkwater 1993, Barton et al. 2003, Thomas et al. 2003). As a shallow embayment connected to the GOM through the intruding branch of the WMCC, MB-CCB likely is affected by climate variability indirectly through changes in the boundary conditions (Jiang et al. 2007b) and directly through changes in surface forcing, such as the sea surface temperature (SST) (Keller et al. 2001) and surface winds (Turner et al. 2006). However, the problem becomes more complicated because signals of largescale variability propagating into coastal regions can be amplified or weakened.

In this study, we examined the horizontal transport and retention of zooplankton by coastal circulation, especially the Lagrangian residual currents, in the MB-CCB system. Using a physical model, observed Calanus finmarchicus abundance data, and right whale sightings, we investigated 2 closely related questions: (1) What is the role of coastal circulation (including coastal current) in the zooplankton abundance and spatial distribution in MB-CCB during springtime? And (2) what are the spatial patterns of particle retention areas in $\mathrm{MB}-\mathrm{CCB}$, and how are they related to the spatial distributions of $C$. finmarchicus abundance and right whale occurrences? We also discuss possible influences of regional scale variability and NAO on the inter-annual variability of $C$. finmarchicus abundance and distribution in the MB-CCB system.

\section{MATERIALS AND METHODS}

A physical model and an embedded particletracking program were used to identify the circulation pattern and the potential retention areas of zooplankton in MB-CCB. Correlations between key parameters were calculated to understand their relationships, in which both zooplankton abundance and right whale sightings were log-transformed. Because of the short time-series (7-8 yr) and sampling limitation (especially zooplankton), the correlation coefficients are sensitive to every one of the observed values. Therefore, a relatively conservative criterion $(p<0.1)$ was used for significance.

Numerical model and particle tracking. Numerical simulations using real forcing data were conducted continuously for the period from 1998 to 2004, although only the spring periods were used for this analysis (there were insufficient data for a 1997 simulation). The numerical model was based on the Estuarine, Coastal, Ocean Model (ECOM-si, Blumberg \& Mellor, 1987, Signell et al. 2000) and had a grid resolution of 1 to $2 \mathrm{~km}$ (in MB-CCB), 12 vertical levels, and a time-step of 207 seconds. The model was forced with hourly meteorological data, daily freshwater discharges, tides, and low-frequency surface slopes at the open boundary. The meteorological inputs were observed winds, air temperature, and air pressure measured at NOAA buoy 44013 (Fig. 1a), solar radiation measured at the Woods Hole Oceanographic Institution, about $25 \mathrm{~km}$ south of $\mathrm{CCB}$, and humidity measured at the Boston Logan Airport. The surface heat fluxes were estimated using a bulk formulation (Weller et al. 1995), and the wind stresses were calculated using the method of Large \& Pond (1981). The model domain covers both MB and CCB, and a portion of western GOM (Fig. 2). The open boundary conditions for temperature and salinity were constructed using an objective interpolation method (Hendry \& He 1996) based on CTD data collected in this area. The surface slope of boundary elevation was estimated from the dynamic height relative to a non-flow surface at $100 \mathrm{~m}$ or at the bottom if the depth is shallower than $100 \mathrm{~m}$. More details of the model can be found in Signell et al. (2000) and Jiang \& Zhou (2004).

A particle-tracking algorithm was embedded in the model to calculate the trajectories of neutrally buoyant particles using same time-step as the model. The algorithm was based on a second-order approximation of advection and a random-walk method for both horizontal and vertical mixing (Hunter et al. 1993). The position $\vec{X}$ of a particle at time $t+\Delta t$ is determined by currents and mixing at the previous location at time $t$ : 

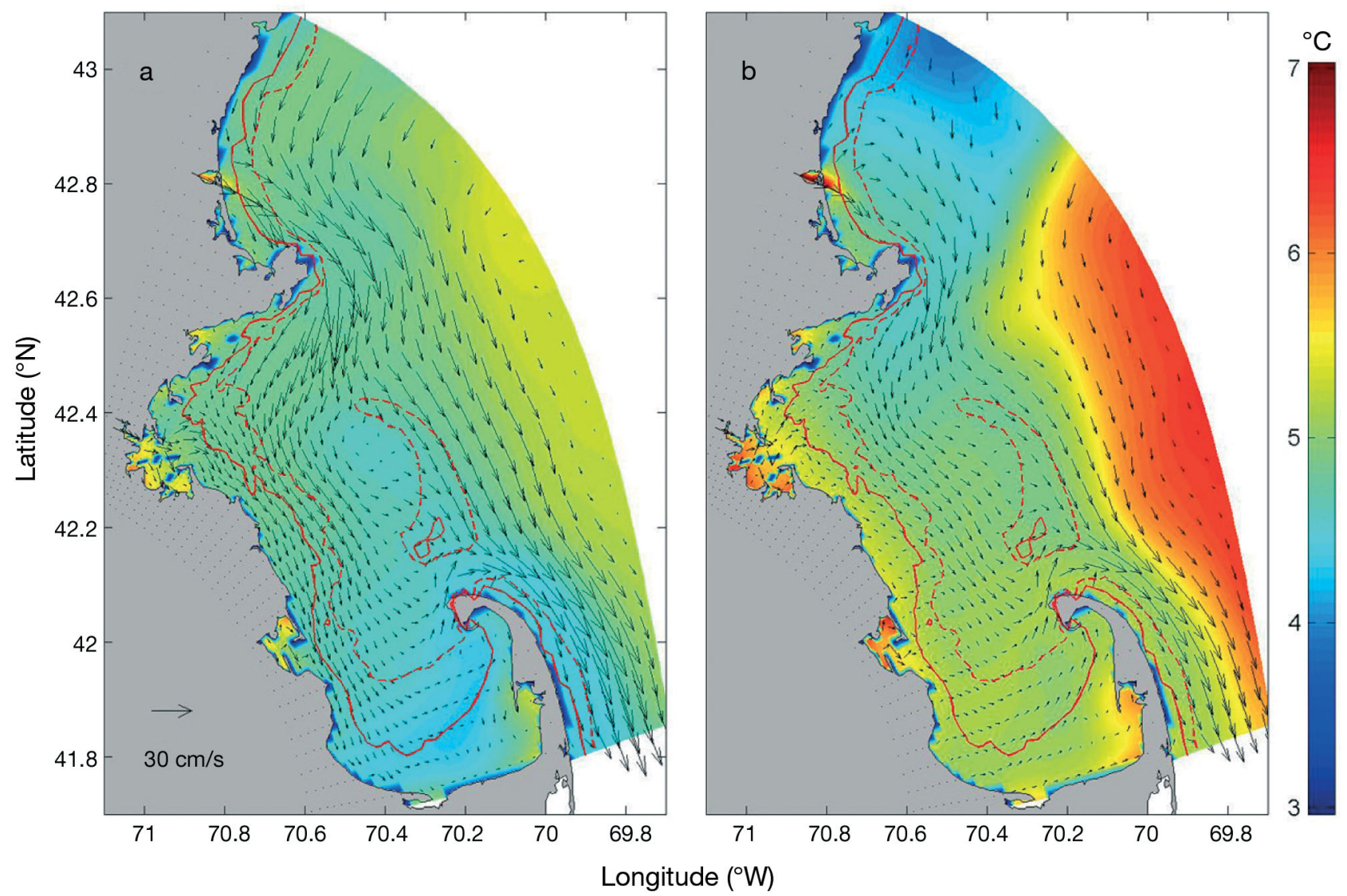

Fig. 2. Modeled surface mean Eulerian currents (arrows) and temperature (color) in (a) March-April 2000 and (b) March-April 2002 using realistic forcing. Solid and dashed red lines indicate the 25 and $40 \mathrm{~m}$ isobaths, respectively

$$
\begin{aligned}
& \vec{X}(t+\Delta t)=\vec{X}(t)+\int_{t}^{t+\Delta t} \vec{V}(\vec{X}(\varsigma), \varsigma) d \varsigma+\vec{V}_{r} \Delta t \cong \\
& \vec{X}(t)+\left(\vec{V}(\vec{X}(t), t)+\frac{d \vec{V}(\vec{X}(t), t)}{d t} \Delta t\right) \Delta t+\vec{V}_{r} \Delta t
\end{aligned}
$$

where $\vec{V}(\vec{X}, t)$ is the particle velocity and $\vec{V}_{r}(\vec{X}, t)$ is the random walk vector representing vertical and horizontal mixing. Each component of $\vec{V}_{r}$ is a random number with zero mean and variance $\operatorname{var}\left(\vec{V}_{r}\right)=2 \vec{K} \Delta t$, where $\vec{K}$ is the mixing coefficient (Hunter et al. 1993).

Particles were initially released from 6 sigma layers at selected model grid points in MB approximately every $15.5 \mathrm{~h}$ for the first $10 \mathrm{~d}$ of numerical experiments and then tracked for 2 mo (Fig. 1b). Two experiments were conducted for each year to obtain the average distribution of particles for March-April: one started in February, and the second month's (March) results were used; the other started in March, and the April results were used. Particles that landed on the coastline were not further tracked and were excluded in the calculation of particle distribution. The mean distribu- tion of particles in the second month of each experiment was calculated by counting particles within each grid cell at every time-step, summing them up over the month, and dividing them by the total time-steps. The final distribution for March-April was the mean of the 2 experiments.

In $\mathrm{MB}-\mathrm{CCB}$, springtime surface winds are primarily northwesterly in most years, but southwesterly winds can dominate in some years (Table 1). In order to understand the general pattern of Lagrangian circulation and the wind effects, we conducted climatological simulations using multi-year means of meteorological parameters (hourly), river flows (daily), open boundary conditions (monthly), and solar radiation (hourly) from 1990 to 2004. Three experiments were conducted using climatological forcing in January and February, and then applying different winds to March-April: (1) no winds, (2) constant northwesterly winds $\left(3 \mathrm{~m} \mathrm{~s}^{-1}\right.$ from $315^{\circ}$ ), and (3) constant southwesterly winds ( $3 \mathrm{~m}$ $\mathrm{s}^{-1}$ from $225^{\circ}$ ). Twenty-five batches of particles were released in the entire bay at various tidal phases (every $15.5 \mathrm{~h}$ ) over a $15 \mathrm{~d}$ period in March. Each batch of 
Table 1. Observed winds at NOAA 44013 (Fig. 1a), and modeled and observed mean currents $\left(\mathrm{cm} \mathrm{s}^{-1}\right)$ at Scituate in March-April from 1997 to 2004. Both winds and currents use oceanographic convention (northward and eastward flows are positive; southward and westward flows are negative). na $=$ not available

\begin{tabular}{|c|c|c|c|c|c|c|}
\hline \multirow{2}{*}{ Year } & \multicolumn{2}{|c|}{- Wind -} & \multicolumn{2}{|c|}{ - Model - } & \multicolumn{2}{|c|}{ Observation } \\
\hline & N-S & E-W & N-S & E-W & N-S & E-W \\
\hline 1997 & -0.9 & 2.0 & na & na & na & na \\
\hline 1998 & -0.63 & 0.56 & -7.0 & 3.5 & -6.6 & 2.8 \\
\hline 1999 & -1.07 & 1.95 & -7.4 & 3.9 & -5.9 & 1.9 \\
\hline 2000 & -0.77 & 0.76 & -5.8 & 2.3 & -3.2 & 0.8 \\
\hline 2001 & -1.48 & 0.63 & -7.2 & 2.6 & -4.3 & 2.3 \\
\hline 2002 & 0.39 & 0.79 & -1.2 & 0.6 & -1.6 & 1.0 \\
\hline 2003 & -0.55 & 0.42 & -4.3 & 1.4 & -5.0 & 2.0 \\
\hline 2004 & -1.25 & 0.17 & -3.0 & 1.1 & na & na \\
\hline
\end{tabular}

particles was tracked for one $\mathrm{M}_{2}$ tidal cycle without including random walk to derive the residual Lagrangian currents. The mean Lagrangian residual currents in the bay were determined by averaging these currents for the 25 batches.

Zooplankton abundances. Zooplankton abundances in MB-CCB have been measured since 1992 as part of an MB monitoring program (Turner et al. 2006). Among the monitoring stations, 4 stations in CCB and 2 stations in the North Passage were occupied 6 times per year (February, April, June, August, October and December) (Fig. 1a). Zooplankton samples were collected by vertical-oblique tows with a $0.5 \mathrm{~m}$ diameter $102 \mu \mathrm{m}$ mesh net within the upper $30 \mathrm{~m}$ of the water column. As Calanus finmarchicus may undergo some diel migration (Durbin et al. 1995a,b), zooplankton may have been under-sampled in areas deeper than $30 \mathrm{~m}$, e.g. the North Passage. Zooplankton were identified to the lowest practical taxon under a dissecting microscope, and counts of all copepodite stages of a given copepod genus were combined. Concentrations of total zooplankton were calculated based on the number of animals counted, divided by the volume of water filtered by the net, and multiplied by the aliquot concentration factor. A more detailed sampling and analysis description can be found in Turner et al. (2006). In this study, we only used the total abundance of $C$. finmarchicus of all copepodite and adult stages for the month of April from 1997 to 2004 to understand the correlation of this copepod with right whale feeding activity. We note that although right whales may mostly feed on older stages of $C$. finmarchicus (Baumgartner \& Mate, 2003), here no distinction was made between younger and older stage animals because of the limited zooplankton data.

Aerial survey of right whales. Aerial surveys were conducted by the Provincetown Center for Coastal
Studies from January through mid-May each year from 1998 through 2004 over CCB and adjacent waters. Fifteen E-W tracklines were flown at 1.5 nautical mile intervals from the mainland to the Cape Cod shoreline. Surveys were flown in a Cessna 337 Skymaster at a standard altitude of 750 feet $(229 \mathrm{~m})$ and a ground speed of approximately 100 knots $\left(185 \mathrm{~km} \mathrm{~h}^{-1}\right)$, using methodology developed by CETAP (CETAP 1982, Scott \& Gilbert 1982). The goal of the aerial surveys was to locate whales, obtain high-quality photographs for individual identification (Kraus et al. 1986), and report those sightings to mariners operating in CCB. A similar survey with same tracklines and protocols was conducted by New England Aquarium in 1997. The survey area covered all of CCB and extended into southern $\mathrm{MB}$ in some years. The area for this analysis was defined as $42^{\circ} 09^{\prime}$ to $41^{\circ} 39^{\prime} \mathrm{N}$, and $70^{\circ} 00^{\prime}$ to $70^{\circ} 39^{\prime} \mathrm{W}$, which was covered every year.

The right whale sighting distributions were used as a surrogate for the distributions of high-density zooplankton patches as zooplankton observations had insufficient temporal and spatial coverage. In order to more quantitatively assess right whale distributions without the potential bias that can be caused by uneven distribution of survey effort, we have used the sightings-per-unit-effort (SPUE) method developed at University of Rhode Island (URI) (CETAP 1982, Kenney \& Winn 1986, Winn et al. 1986). Here we used a SPUE dataset compiled for another study (O. C. Nichols, M. W. Brown \& R. D. Kenney unpubl.).

The study area was partitioned into a grid of 117 cells, each measuring 3 min of latitude ( $3 \mathrm{n}$ miles/ $5.6 \mathrm{~km})$ by $3 \mathrm{~min}$ of longitude $(2.2 \mathrm{n}$ miles $/ 4.1 \mathrm{~km})$, excluding all cells over land. Survey data are comprised of a chronological sequence of latitude/longitude points that describe the path flown by the aircraft. The survey 'effort' is defined as the length of the segment between each successive pair of points (Kenney \& Winn 1986). For each survey, each track segment was partitioned into smaller sections contained within the separate 3 min cells. In order to standardize effort further, only segments completed with visibility at least $2 \mathrm{n}$ miles, sea state of Beaufort 3 or lower, aircraft

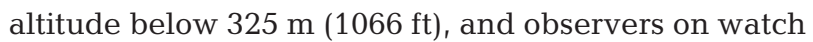
were included. Similarly, only right whales sighted under those defined valid effort conditions were included. Total effort and total right whales sighted within each cell were summed by 2 wk period and yr, and then the number of whales sighted was divided by effort to generate the SPUE index, in units of whales sighted per $1000 \mathrm{~km}$ of valid effort. Only data collected in March and April have been used in this manuscript. Since a strong correlation exists between total numbers of right whale sightings and SPUE $\left(r^{2}=0.97\right)$, we will only use SPUE hereafter. 


\section{RESULTS}

\section{Circulation}

Driven by the intruding branch of the WMCC, local freshwater input and wind forcing, the typical MB-CCB circulation pattern in spring is counterclockwise, with the intruding current flowing along the western coast, turning eastward near Plymouth Harbor, and finally exiting MB through the South Passage, as seen in spring 2000 (Fig. 2a; Geyer et al. 1992, Jiang \& Zhou 2004, Jiang et al. 2007a,b). Consistent with the circulation pattern, currents at Scituate are persistently southward (Fig. 3) and the currents in CCB are normally weak.

This circulation pattern, however, is subject to significant inter-annual variability. In spring 2002, for example, the coastal current was much weaker and stayed offshore, flowing southeastward directly toward the South Passage, largely bypassing CCB (Fig. 2b). Currents at Scituate were much weaker than during normal years and changed direction more frequently,
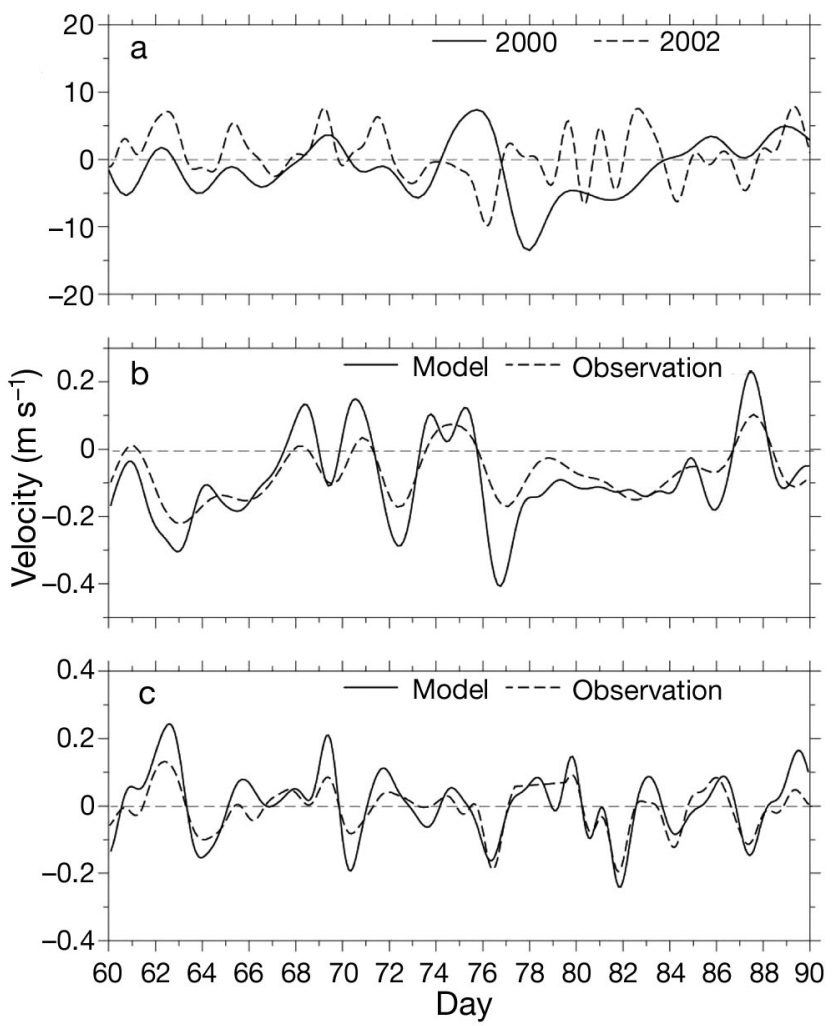

Fig. 3. (a) N-S velocities of winds at NOAA buoy 44013 (see Fig. 1a) in March, (b) N-S velocities of modeled surface currents and observed surface currents at USGS Scituate buoy in 2000, and (c) 2002. Positive values indicate a wind or current directed toward the north, i.e. a southerly wind or a northward current. Model results are derived from simulations using realistic forcing largely due to more frequent southwesterly winds (Fig. 3). As a consequence, CCB was more quiescent and isolated in spring 2002 than in normal years. Numerical simulations indicate that spring circulation patterns from 1998 to 2004 were all similar to those in 2000, except for 2002.

The inter-annual variability of MB-CCB circulation can be further illustrated by the variability of the mean springtime (March-April) coastal current (Fig. 4). Both the model and observed coastal currents exhibit a strong inter-annual variability in both N-S and E-W components (Table 1). In general, the E-W component of the coastal current is less than half of, and linearly correlated with the N-S component $\left(\mathrm{r}^{2}=0.86\right.$ for the model and $\mathrm{r}^{2}=0.70$ for observation, respectively). The model reproduces the strength and variability of the observed coastal current reasonably well, especially for the N-S component $\left(\mathrm{r}^{2}=0.6, \mathrm{p}<0.05\right)$.

\section{Eulerian and Lagrangian residual circulations}

The patterns of mean Eulerian and Lagrangian circulation share several features (Figs. 5a,b): an overall counter-clockwise circulation with 2 cyclonic eddies in central CCB and the central Stellwagen Basin, respectively, and an anti-cyclonic eddy on top of the Massa-
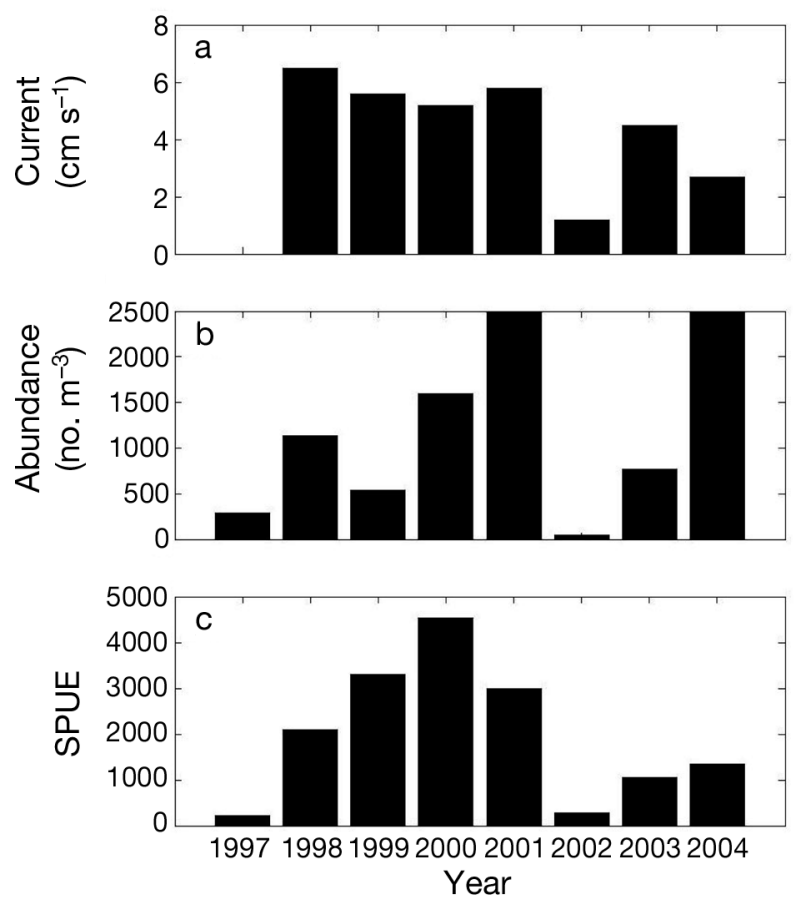

Fig. 4. Time-series of (a) model mean coastal current at Scituate (within $10 \mathrm{~km}$ of the coastline), (b) mean Calanus finmarchicus abundance in Cape Cod Bay (CCB), and (c) right whale sightings-per-unit-effort (SPUE) (whales per $1000 \mathrm{~km}$ of survey track) in spring 1997-2004. C. finmarchicus abundance was capped at 2500 ind. $\mathrm{m}^{-3}$ 


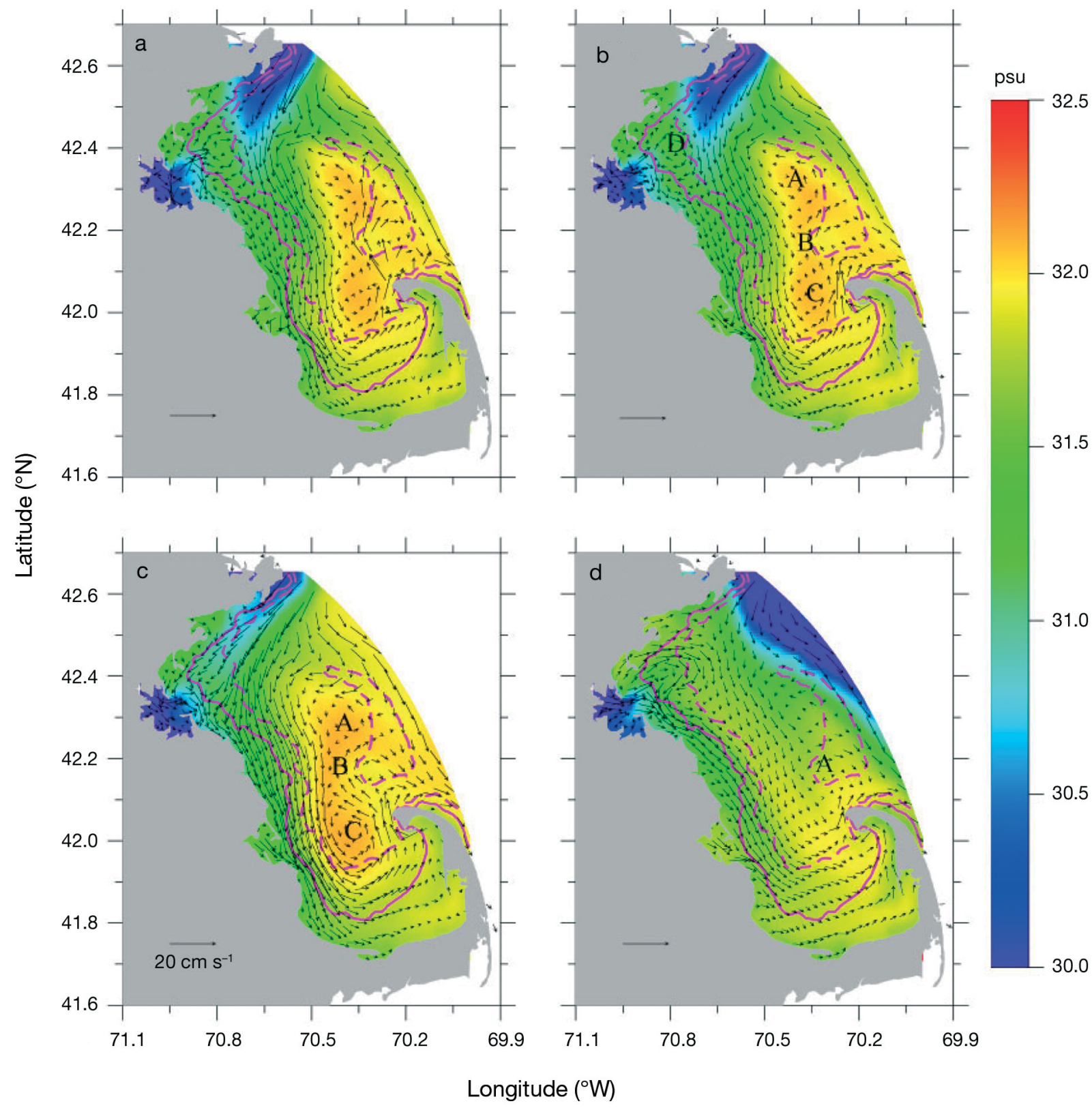

Fig. 5. Surface residual currents (arrows) and salinity (color) in March from the climatological experiments: (a) Eulerian residual currents without wind, (b) Lagrangian residual currents without wind, (c) Lagrangian residual currents under constant northwesterly winds, and (d) Lagrangian residual currents under constant southwesterly winds. Labels A, B, C and D indicate the fixed-points. Solid and dashed magenta lines indicate 25 and $40 \mathrm{~m}$ isobaths, respectively

chusetts Water Resources Authority (MWRA) outfall (Fig. 1a), produced by the freshwater from the effluent (Signell et al. 2000). The mean Lagrangian currents on top of Stellwagen Bank and in the South Passage, however, are much weaker than the mean Eulerian currents because the directions of the Stokes drifts (not shown) are generally opposite those of the Eulerian currents, consistent with the model results by Loder et al. (1997) for Georges Bank. We note that in simulations with real forcing, the difference between the Eulerian and Lagrangian circulations may be more significant, as forcing conditions such as winds vary dramatically. In these cases, it is the Lagrangian residual currents that control the long-term distribution of particles.

The residual circulation pattern is closely associated with the salinity distribution (Fig. 5). Freshwater plumes from the Merrimack River $(20 \mathrm{~km}$ north of Cape Ann) and Boston Harbor, which mix with the 
GOM intruding waters and occupy most of the MB$\mathrm{CCB}$, can be clearly identified. Waters with relatively high salinity reside on top of the bank and in southern Stellwagen Basin. As a result, a strong salinity front is formed, which starts from the northern tip of the bank, crosses the central basin, and then penetrates into central CCB following the $40 \mathrm{~m}$ isobath. However, the salinity front is not associated with a thermal front in spring (not shown).

Under northwesterly wind conditions, both the GOM intruding current and coastal current are significantly enhanced, which disrupts the freshwater eddy near the outfall and weakens the eddy in central Stellwagen Basin, but strengthens the central CCB eddy (Fig. 5c). As a result, the salinity front is also enhanced. By contrast, under southwesterly wind conditions, both the intruding current and coastal current are significantly reduced. The Merrimack River plume is blocked from

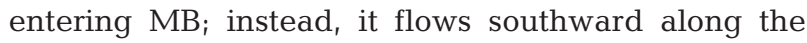
eastern flank of the bank. As a result, the freshwater eddy on top of the outfall is enhanced but somewhat distorted, while the eddy in Stellwagen Basin is much weaker (Fig. 5d). The eddy in CCB is disrupted and shifted northward, becoming a broad, slow-motion zone between central Stellwagen Basin and Race Point.

In a 2-dimensional flow, the pattern of mean particle distribution is determined by the so-called fixed points (where currents are zero) and their stable and unstable manifolds of the Lagrangian residual circulation (Ottino 1989, Ridderrinkhof \& Loder 1994). There are 2 types of fixed points: (1) elliptic points where surrounding currents can be represented by pure rotations and (2) hyperbolic points (saddle points) where currents are convergent in 1 characteristic axis and divergent in another. In the MB-CCB circulation system, there are 3 elliptic points (A, C and D) and 1 hyperbolic point (B) under no-wind conditions (Fig. 5b). The streamline connecting with the hyperbolic point B defines the boundaries (called separation lines) for both eddies A and C. By contrast, under southwesterly winds, fixed points $\mathrm{A}$ and $\mathrm{C}$ disappear and are replaced by a broad slow-flow area (denoted as A) noted above (Fig. 5d).

The dynamics involved in these fixed points and the manifolds are nonlinear and complicated, as both Eulerian and Lagrangian circulation here are not strictly 2-dimensional and the currents are under periodic forcing by tides and winds. For our purpose, it is sufficient to note that the trajectories of particles approaching point B could be either regular oscillations or chaotic oscillations around the separation line and that particles will take a very long time to reach B (Zimmermann 1981, Ridderinkhof \& Loder 1994). In the former case, little water exchange occurs between eddies $\mathrm{A}$ and $\mathrm{C}$ and surrounding waters, and particles inside both eddies are less likely to escape. In the latter case, particles may cross the boundary frequently and significant water exchange may occur. In either case, the areas surrounding the separation lines are areas with high probability of particle presence.

\section{Calanus finmarchicus abundance and right whale sightings}

Both Calanus finmarchicus abundance and whale sightings in spring show strong inter-annual variability (Fig. 4b,c). Moreover, C. finmarchicus abundance appears to be correlated with the presence of right whales following a power relationship $\left(\mathrm{r}^{2}=0.42\right.$, $\mathrm{p}<0.1$, Table 2). Excluding the abnormally high C. finmarchicus abundance in 2004, the correlation increases to $\mathrm{r}^{2}=0.63(\mathrm{p}<0.05)$.

The coastal transport (equivalent to mean coastal current, see Fig. 4) in MB-CCB may play an important role in Calanus finmarchicus abundance and right whale occurrence in CCB. A strong coastal transport at Scituate generally corresponds to high C. finmarchicus abundance and right whale SPUE in $\mathrm{CCB}$, except in 1999 when $C$. finmarchicus abundance was relatively low. Conversely, the low coastal transport in 2002 was associated with extremely low C. finmarchicus abundance and right whale SPUE (Fig. 4). Though no correlation between the $C$. finmarchicus abundance and coastal transport is found when using all available data, a strong correlation exists when excluding the 2004 data $\left(r^{2}=0.68, y=34.7 \mathrm{e}^{0.74 x}, \mathrm{p}<0.05\right)$. By contrast, the coastal transport has a much stronger correlation with the SPUE $\left(\mathrm{r}^{2}=0.87, \mathrm{p}<0.01\right)$, suggesting that the coastal transport is linked to the distribution of $C$. finmarchicus, rather than its abundance.

\section{Particle and whale sighting distributions}

The mean model particle distributions from 2000 to 2003 show a strikingly coherent pattern in 3 of the 4 years, with the exception of 2002 (Fig. 6). Specifically, particles accumulate in a SW-NE band that stretches from Barnstable Harbor to Race Point and circles around the outer tip of Cape Cod, occupying the entire South Passage. This area also extends northwestward into southern Stellwagen Basin. A second and smaller retention area is located in central Stellwagen Basin, which normally has fewer particles than the CCB retention area. Particles also accumulate in nearshore areas. This pattern is consistent with the pattern of Lagrangian residual currents in the climatological experiments under no-wind or northwesterly wind 
Table 2. Correlations between key variables in the Massachusetts Bay-Cape Cod Bay (MB-CCB) system from 1997 to 2004. NAO: North Atlantic Oscillation; SPUE: sightings-per-unit-effort; ns: not significant; na: not available

\begin{tabular}{|c|c|c|c|c|c|}
\hline Parameter $x$ & Parameter $y$ & $\mathrm{n}$ & $r^{2}$ & $\mathrm{p}$ & Regression equation \\
\hline $\begin{array}{l}\text { NAO } \\
\text { winter index }\end{array}$ & $\begin{array}{l}\text { N-S velocity of winds at NOAA } 44013 \text { (Fig. 1a) } \\
\text { Model along-shelf transport at Scituate } \\
\text { Calanus finmarchicus in the North Passage } \\
\text { C. finmarchicus in CCB } \\
\text { Right whale sightings (SPUE) in CCB }\end{array}$ & $\begin{array}{l}8 \\
7 \\
8 \\
8 \\
8\end{array}$ & $\begin{array}{l}0.43^{\mathrm{a}} \\
0.51 \\
0.36^{\mathrm{b}} \\
\mathrm{ns} \\
\mathrm{ns}^{\mathrm{c}}\end{array}$ & $\begin{array}{c}<0.1 \\
<0.05 \\
0.1 \\
\text { na } \\
\text { na }\end{array}$ & $\begin{array}{c}y=-1.08 x+1.16 \\
y=-3.0 x+5.0 \\
y=719.0 \mathrm{e}^{1.46 x}\end{array}$ \\
\hline $\begin{array}{l}\text { N-S velocity } \\
\text { of winds at } \\
\text { NOAA } 44013 \text { (Fig. 1a) }\end{array}$ & $\begin{array}{l}\text { Model along-shelf transport at Scituate } \\
\text { C. finmarchicus in CCB } \\
\text { Right whale sightings (SPUE) in CCB }\end{array}$ & $\begin{array}{l}7 \\
7 \\
8\end{array}$ & $\begin{array}{l}0.55 \\
0.67 \\
0.29\end{array}$ & $\begin{array}{l}<0.05 \\
<0.05 \\
<0.1\end{array}$ & $\begin{array}{l}y=1.9 x+2.5 \\
y=146.3 \mathrm{e}^{2.29 x} \\
y=563.1 \mathrm{e}^{1.07 x}\end{array}$ \\
\hline $\begin{array}{l}\text { Model alongshelf } \\
\text { transport at Scituate }\end{array}$ & $\begin{array}{l}\text { C. finmarchicus in CCB } \\
\text { Right whale sightings (SPUE) in CCB }\end{array}$ & $\begin{array}{l}7 \\
7\end{array}$ & $\begin{aligned} \mathrm{ns}^{\mathrm{d}} \\
0.87\end{aligned}$ & $\begin{array}{c}\text { na } \\
<0.05\end{array}$ & $y=157.0 \mathrm{e}^{0.58 x}$ \\
\hline $\begin{array}{l}\text { C. finmarchicus } \\
\text { in the North Passage }\end{array}$ & C. finmarchicus in CCB & 8 & ns & na & \\
\hline 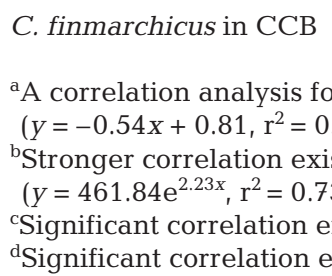 & $\begin{array}{l}\text { Right whale sightings (SPUE) in CCB } \\
\text { a longer period (1985-2004) yielded a more sign } \\
0, \mathrm{p}<0.05) \\
\text { s when excluding } 1997 \text { zooplankton with } C \text {. fina } \\
\mathrm{p}<0.05) \\
\text { ists when excluding } 2000 \text { data }\left(y=2400 \mathrm{e}^{-2.76 x}, \mathrm{r}^{2}\right. \\
\text { ists when excluding } 2004 \text { data }\left(y=34.7 \mathrm{e}^{0.74 x}, \mathrm{r}^{2}=\right.\end{array}$ & 8 & $\begin{array}{l}\text { correlc } \\
15 \text { lage } \\
p<0.0 \\
<0.05\end{array}$ & $<0.1$ & $y=5.72 x^{0.46}$ \\
\hline
\end{tabular}

conditions. The retention area in CCB is clearly associated with the southern boundary of the eddy defined by fixed points $B$ and $C$, while the retention area in central Stellwagen Basin is associated with the eddy defined by A and B (Figs. 5 to 7). One explanation for low particle density within eddy $\mathrm{C}$ is that there is little water exchange between the eddy and surrounding waters. Since particles were released uniformly in $M B$, most particles circle around eddy $\mathrm{C}$ and are less likely to be entrained into it. Similar distributions of particles can be expected for 1998 through 1999 and for 2004 since springtime circulations in these years were very similar to those in 2000, 2001 and 2003.

The pattern in March-April 2002, however, is dramatically different. While the South Passage remains an area of high particle accumulation, there is essentially no accumulation in CCB. By contrast, many particles accumulate and distribute evenly over southern Stellwagen Basin and a small patch of particles appears over the western flank of Stellwagen Bank. This is consistent with the pattern of Lagrangian residual currents in the climatological experiment under southwesterly wind conditions, in which the CCB eddy is shifted northward and replaced by a slow-motion zone A (Fig. 5d).

Right whale sighting distribution in CCB also has a strikingly coherent pattern in 2000, 2001 and 2003, with whales aggregated over a band stretching from Barnstable Harbor to Race Point (Fig. 7). The patterns of SPUE in 1998 through 1999 and 2004 are very similar (not shown), though the values vary over the years. The limited Calanus finmarchicus abundance data suggest that whale aggregations correlate with $C$. finmarchicus abundance, consistent with results from previous studies (e.g. Murison \& Gaskin 1989, Baumgartner \& Mate 2003, Baumgartner et al. 2003, Mayo et al. 2004). Moreover, the area of high whale density closely matches the modeled particle retention area in CCB. By contrast, low density of model particles in CCB during spring 2002 corresponded to very low whale occurrences and low C. finmarchicus abundance. Note that in spring 2002, few whales were sighted in the area of southern Stellwagen Basin where model particles accumulated.

We note that since in these simulations particles were released in MB only, particles would generally spend more time in CCB than in MB. Therefore, particle distribution should be viewed as a measure for the potential accumulation area. They are by no means evidence of the real zooplankton distributions.

\section{Surface winds, Calanus finmarchicus abundance in the GOM, and NAO}

The NAO may affect the MB-CCB system through the changes in the GOM. Therefore, we also present the surface winds (March-April) at NOAA 44013 


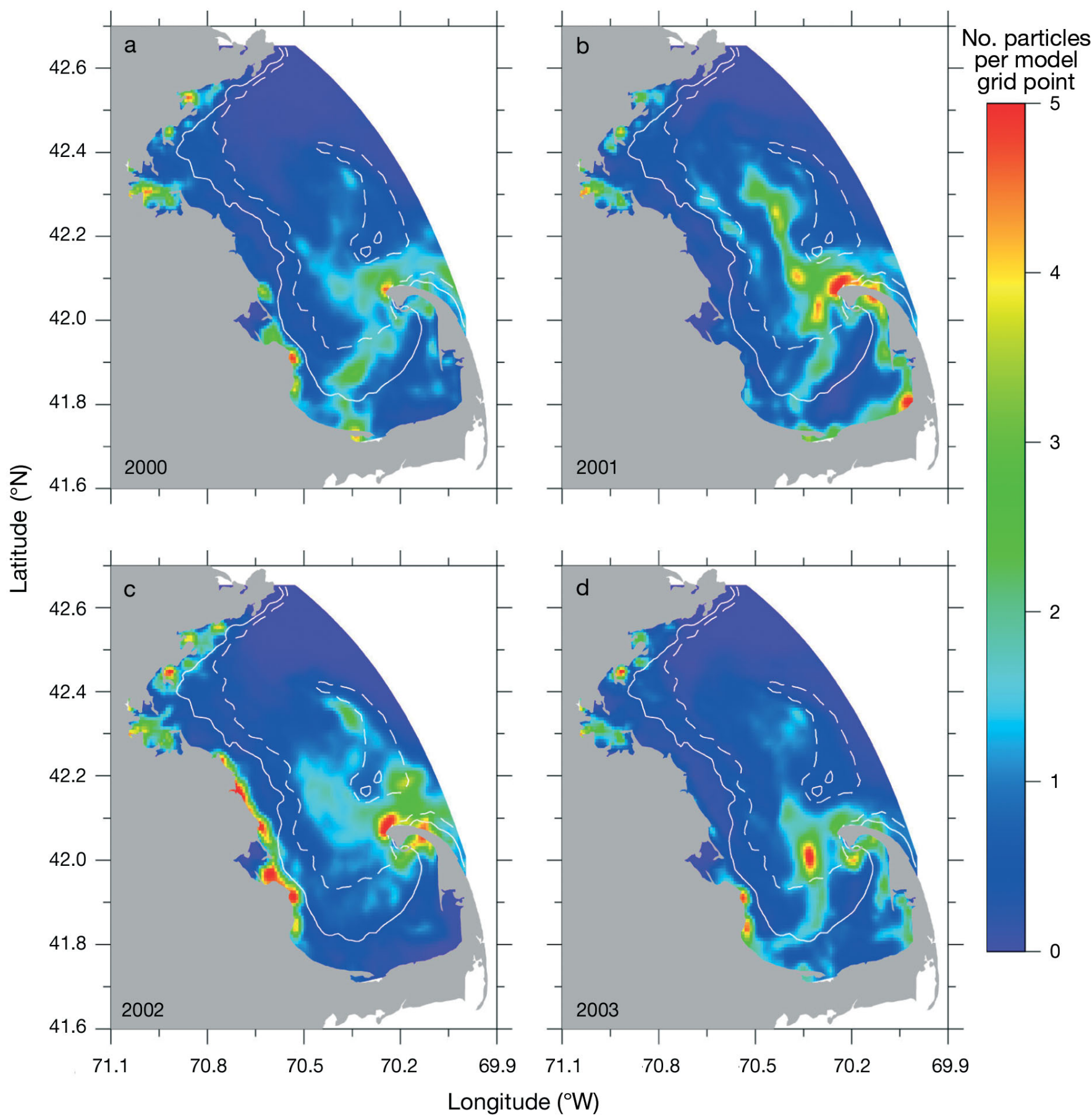

Fig. 6. Average densities of modeled particles in March-April from 2000 to 2003 using realistic forcing. Solid and dashed lines indicate 25 and $40 \mathrm{~m}$ isobaths, respectively

(Fig. 1a), Calanus finmarchicus abundance in the North Passage (April only) representing the abundance in the GOM intruding current, and the winter NAO index from 1997 to 2004 (Fig. 8, Table 2).

The winter NAO index has a weak correlation with Calanus finmarchicus abundance lagging behind about $1 \mathrm{yr}$ (Table 2), which is consistent with the results found in the GOM region (Conversi et al. 2001, Greene \& Pershing 2000, Greene et al. 2003). However, no correlation was found between the NAO index and $C$. finmarchicus abundance in $\mathrm{CCB}$ or between $C$. finmarchicus abundances in the North 


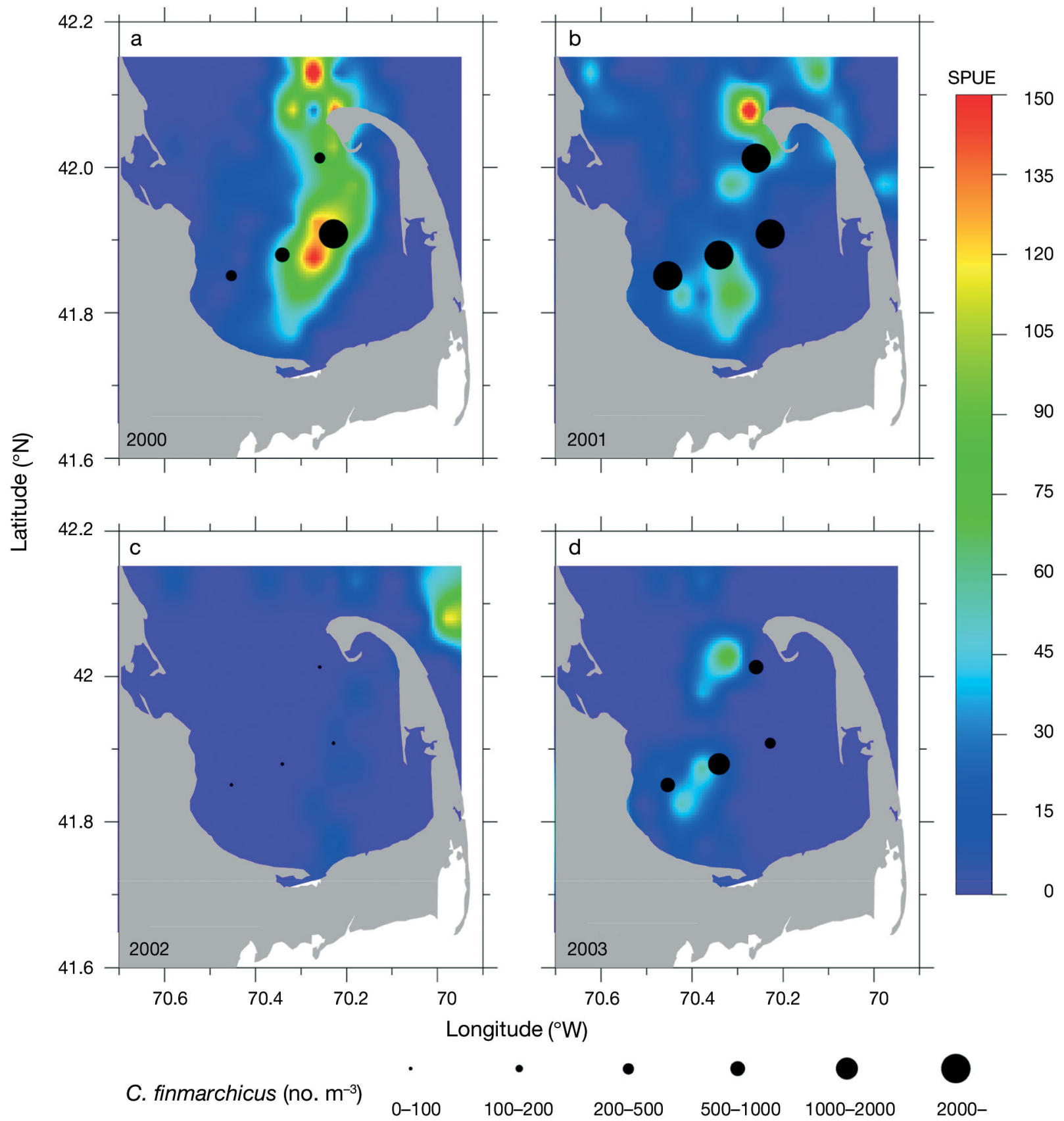

Fig. 7. Eubalaena glacialis. Yearly mean right whale sightings-per-unit-effort (SPUE) (whales per $1000 \mathrm{~km}$ of survey track) in CCB in March-April from 2000 to 2003. Mean Calanus finmarchicus abundances for the same time periods at 4 sampling stations in $\mathrm{CCB}$ are also shown

Passage and in CCB. On the other hand, the winter NAO index may be inversely correlated with the N-S velocity of surface winds at NOAA 44013 in March-April $\left(\mathrm{r}^{2}=0.43, \mathrm{p}<0.1\right)$ but not with the E-W component of surface winds. A significant exponential correlation exists between the N-S component of surface winds and $C$. finmarchicus abundance in CCB as well as the SPUE. Furthermore, the N-S com- ponent of surface winds has a significant correlation with model alongshelf transport at Scituate $\left(\mathrm{r}^{2}=0.55\right.$, $\mathrm{p}<0.05$, Table 2), whereas the E-W component of surface winds does not correlate with model transport. Hence the NAO appears to have influenced the MB-CCB C. finmarchicus abundance mainly through surface winds and coastal circulation, but not through boundary inputs. 

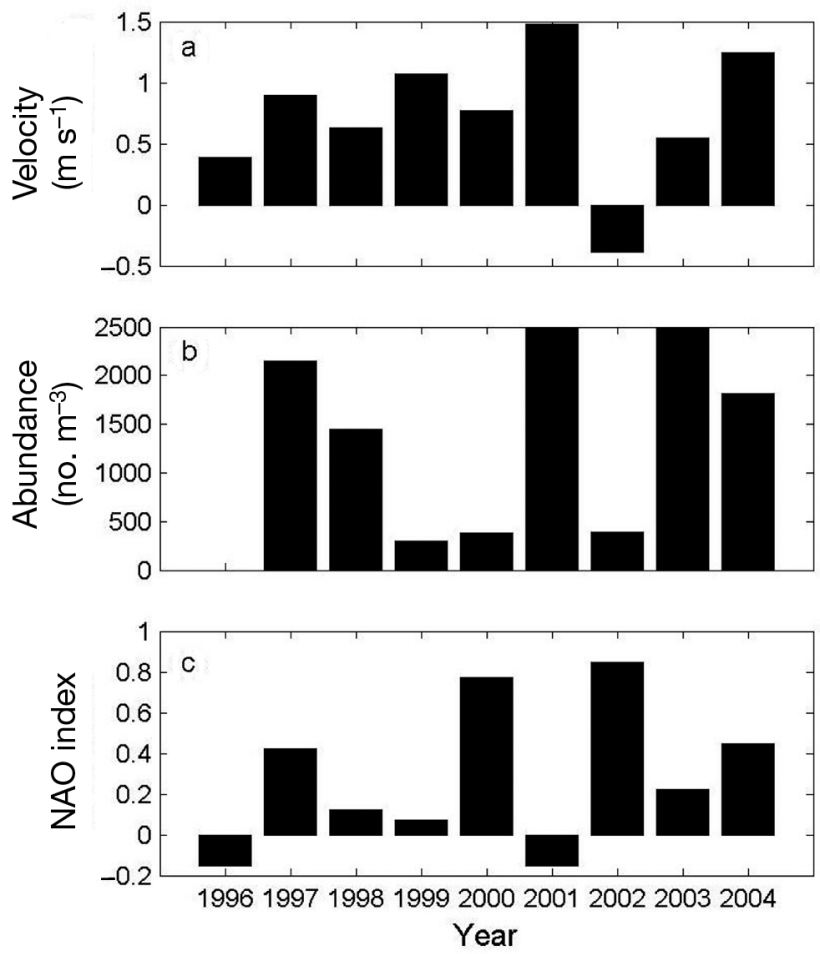

Fig. 8. Time-series of (a) N-S wind velocity (southward positive) measured at NOAA buoy 44013 (March-April), (b) Calanus finmarchicus abundance at MWRA station F27 (located in the North Passage) in April (no observation available for 1996), and (c) winter North Atlantic Oscillation (NAO) index (source: www.cpc.ncep.noaa.gov/products/ precip/CWlink/pna/nao.html)

\section{DISCUSSION}

\section{Transport and retention of Calanus finmarchicus, and right whale feeding}

Our model and observational results suggest an important role of Lagrangian circulation in controlling Calanus finmarchicus abundance and distribution in the MB-CCB system through coastal transport of C. finmarchicus and the formation of water-parcel retention areas. Since CCB is too shallow for $C$. finmarchicus over-wintering, local populations must be replenished annually from the deep basins of the GOM through the intruding current. Thus, a strong intruding current and a persistent southward coastal transport (as in normal years) are critical to C. finmarchicus in $\mathrm{CCB}$, which is consistent with the significant correlation between coastal transport (equivalent to mean coastal current) at Scituate and right whale sightings in CCB (Fig. 4, Table 2). A stronger coastal transport, on the other hand, would imply a shorter residence time of water parcels in western MB and possibly a smaller locally-produced younger generation of C. finmarchi- cus. This is consistent with the negative correlation between the $C$. finmarchicus abundance in western MB and wind speed at NOAA 44013 (Turner et al. 2006), since higher wind speed would generally imply stronger coastal current.

Coastal transport is closely associated with the patterns of Lagrangian residual circulation and particle retention in the MB-CCB system (Figs. 5 \& 6). In normal years, a strong (southward) transport persists along with 2 prominent eddies, in central CCB and central Stellwagen Basin, respectively, which correspond to 2 particle retention areas. On the other hand, during a year with dominant southwesterly winds in spring, coastal waters would be pushed offshore by Ekman transport, which in turn would reduce or even reverse the coastal current, hence substantially decreasing water transport from MB into CCB (Fig. 5d). The intruding current from the GOM would tend to stay offshore and may even bypass CCB, as seen in 2002. As a consequence, zooplankton in $\mathrm{MB}$ is less likely to be transported into CCB. Moreover, the retention center in $\mathrm{CCB}$ is no longer present; thus, zooplankton in $\mathrm{CCB}$ is likely to be more uniformly distributed.

It is well known that right whales tend to feed on zooplankton patches, especially those of Calanus finmarchicus (Murison \& Gaskin 1989, Mayo \& Marx 1990, Kenney et al. 1995, Baumgartner \& Mate 2003, Baumgartner et al. 2003). Therefore, the close matches of the right whale aggregations with the particle retention areas and high $C$. finmarchicus abundance in CCB (Figs. $6 \& 7$ ) suggest that the model particle retention area in CCB is favorable to zooplankton aggregation. Furthermore, disruption of the typical circulation with lower coastal transport, such as in 2002, would lead to very low particle accumulation in $\mathrm{CCB}$, which was coincident with very low right whale presence. This suggests that $C$. finmarchicus abundance in CCB was significantly reduced as well and that right whales might have sought out other potential feeding areas, such as the Great South Channel.

During normal years, the prevailing winds generally switch to southwesterly as the season progresses into May and June. The coastal current becomes weaker and it is likely that the retention zone in CCB also shifts northward, which may partly explain why right whales normally leave CCB in late April and early May. Another possible reason for the departure of right whales may be the seasonal decline of Calanus finmarchicus abundance, which normally starts in late April or May in MB-CCB (Turner et al. 2006).

Model results suggest that retention centers in $\mathrm{CCB}$ and the Stellwagen Basin appear to be created either by the closing of the eddy or following the convergent limb of the unstable manifolds (Figs. 5 \& 6). Alternatively, these retention zones may be purely due to the 
convergence of waters in that area. The convergence pattern (not shown), however, is clearly different from the pattern of retention zones, although some broad correlation may exist. In spring 2000, for example, the convergent zone in $\mathrm{CCB}$ was about $10 \mathrm{~km}$ southeast of the retention zone. A possible reason for this mismatch is that particle retention is a result of non-linear and long-term movement of particles, which reflects the global topological characteristics of a flow field, especially when a non-steady flow is involved. In contrast, the divergence/convergence of a mean flow field can only provide the local characteristics of the circulation.

\section{Physical-biological interactions}

The present study did not examine the effects of biological processes in $\mathrm{CCB}$, such as local production, zooplankton behavior, and whale feeding behavior. Many questions remain to be answered. First, does local growth play an important role in zooplankton abundances and distributions? Springtime is the fastest growing season for Calanus finmarchicus. Waters in $\mathrm{CCB}$ tend to be warmed up earlier than in $\mathrm{MB}$ such that spring bloom in CCB generally takes place earlier (Jiang et al. 2007a,b). Therefore, local growth may contribute to the spatial heterogeneity of $C$. finmarchicus abundance. Secondly, how do zooplankton and right whales interact with aspects of the micro-physical environment, such as residual currents and turbulent intensity? Does $C$. finmarchicus exhibit diel vertical migration behavior in $\mathrm{CCB}$ and, if so, how does this interact with the physical environment to create the vertical patches? Durbin et al. $(1995 \mathrm{a}, \mathrm{b})$ found that diel migration of $C$. finmarchicus in the Great South Channel changed within seasons and between years. Modeling studies have suggested that vertical swimming behavior might help zooplankton maintain vertical depth and form patches in a convergent tidal front (Franks 1992, Beardsley et al. 1996, Epstein \& Beardsley 2001). A weak front can also be identified around the retention areas in MB-CCB (Fig. 5), which suggests frontal processes may be important as well. Thirdly, do right whales feed on other types of zooplankton when C. finmarchicus is scarce? For example, other zooplankton components need to be taken into account to better explain the 1999 mismatch between C. finmarchicus abundance and whale sightings (Fig. 4). Right whales in CCB are known to feed at times on other copepods and on planktonic barnacle larvae (Mayo \& Marx 1990). Also, it is unclear why there was only moderate presence of right whales in spring 2004 given the high abundance of $C$. finmarchicus. The limited temporal and spatial coverage of in situ sampling of zooplankton may not be able to capture the patchy distribution of $C$. finmarchicus. Another important factor here is the availability of prey for the whales in alternative habitats. In 1999, whale presence in CCB was higher than C. finmarchicus abundance would suggest, possibly because prey (including $C$. finmarchicus) levels were even worse elsewhere (e.g. Great South Channel, Wildcat Knoll, the Northern Edge, Cashes Ledge). Conversely, in 2004, whale presence in CCB was lower than suggested by the model and $C$. finmarchicus abundance, possibly because Calanus densities elsewhere were unusually high.

\section{Regional and NAO influences on Calanus finmarchicus in MB-CCB}

The MB-CCB system is likely influenced by regional processes in the GOM through open-boundary forcing and large-scale climate variability such as the NAO. The physical-biogeochemical processes in the GOM are also modulated by large-scale circulation and climate change (Petrie \& Drinkwater 1993, Greene \& Pershing 2000, Barton et al. 2003, Greene et al. 2003, Thomas et al. 2003). Thus, large-scale variability such as the NAO may affect the MB-CCB system directly through surface forcing or indirectly through the variability of boundary conditions.

In the case of Calanus finmarchicus, the lack of correlation between $C$. finmarchicus abundance in the North Passage and that in CCB (Table 2) suggests little direct influence of boundary conditions on $C$. finmarchicus abundance. This may also be due to the limited sampling frequency and depth (upper $30 \mathrm{~m}$ ) of zooplankton in the North Passage. However, there are still possible indirect influences of boundary conditions through the GOM (including current, nutrients and phytoplankton) which might affect MB circulation, zooplankton distribution, and zooplankton development. For example, Jiang et al. (2006b) suggested that the boundary inputs of phytoplankton from the GOM may significantly affect the MB spring bloom.

Our data and model results suggest that the NAO may mostly influence Calanus finmarchicus distribution instead of abundance in CCB through surface winds. While little is known about the specific linkage between the NAO and local winds in the GOM region, it is generally recognized that during positive NAO phases, mid-latitude westerly winds are strengthened by the enhanced atmospheric pressure gradient over the North Atlantic (e.g. Dickson et al. 1996). This is consistent with our analysis, which suggests that the NAO may have contributed about 20 to $40 \%$ to the variability of $\mathrm{MB}$ winds during March-April (Table 2). Changes in surface winds may in turn affect MB-CCB 
circulation, including the coastal current (Figs. 2 \& 3), and consequently, zooplankton distribution in MBCCB (Figs. 6 \& 7). The potential correlations between surface winds, NAO winter index, and coastal transport (Table 2) and the close match of particle retention with right whale sighting distributions (Figs. 6 \& 7) support this scenario. This is consistent with the results of Turner et al. (2006), who found a significant negative correlation between wind speed and $C$. finmarchicus abundance in western MB in the period from 1992 to 2003. As noted above, stronger wind speed generally indicates a stronger coastal current that removes C. finmarchicus faster from western $\mathrm{MB}$ into $\mathrm{CCB}$. Hence, $C$. finmarchicus abundance in western $\mathrm{MB}$ and CCB tends to have opposite relationships with winds. An exception to this was the low C. finmarchicus abundance and SPUE in CCB in 1997, even though winds were predominantly northwesterly that year (Fig. 4). One possible cause is the 2 severe snowstorms that occurred in March-April 1997 (the second was the biggest late-season storm ever recorded in Boston), which might have severely disrupted the zooplankton community.

Overall, Calanus finmarchicus in the MB-CCB system is more likely affected by large-scale variability through local processes than boundary inputs. However, this analysis is suggestive rather than conclusive because of the limited availability of data. For example, the shortness of the time-series means that correlations between parameters may change significantly by just adding or removing one data point (Table 2). This study represents a first step toward understanding the potential role of circulation in zooplankton abundance and distribution in this area. More zooplankton data are needed to understand the spatial patterns and their underlying dynamics, such as the interactions of physical processes with aggregation. Longer time-series of hydrology, zooplankton and whales also are needed to examine the potential temporal correlations. A zooplankton population model coupled with the physical model will be helpful in examining the role of local growth and production.

Acknowledgements. M.S.J. and M.Z. are supported by a cooperative agreement between the University of Massachusetts Boston and the MWRA. R.D.K. is supported through a NOAA Cooperative Marine Education and Research grant. J.T.T. is supported by the MWRA. Winds at NOAA 44013 and measurements of currents at the USGS Buoy B were provided by B. Butman at the USGS. D. Payne at WHOI provided the solar radiation data for the model. The right whale data were collected by Provincetown Center for Coastal Studies under contract to the Division of Marine Fisheries, Massachusetts. Right whale research was conducted under Scientific Permit to Take Marine Mammals, number 633-1483-06, issued from NOAA Fisheries to C.A.M. Four anonymous reviewers' comments greatly improved the manuscript.

\section{LITERATURE CITED}

Barton AD, Greene CH, Monger BC, Pershing AJ (2003) The continuous plankton recorder survey and the North Atlantic Oscillation: interannual- to multidecadal-scale patterns of phytoplankton variability in the North Atlantic Ocean. Prog Oceanogr 58:337-358

Baumgartner MF, Mate BR (2003) Summertime foraging ecology of North Atlantic right whales. Mar Ecol Prog Ser 264: 123-135

Baumgartner MF, Cole TVN, Clapham PJ, Mate BR (2003) North Atlantic right whale habitat in the lower Bay of Fundy and on the SW Scotian Shelf during 1999-2001. Mar Ecol Prog Ser 264:137-154

Beardsley RC, Epstein AW, Chen C, Wishner KF, Macaulay MC, Kenney RD (1996) Spatial variability in zooplankton abundance near feeding right whales in the Great South Channel. Deep-Sea Res II 43:1601-1625

Bigelow HB (1927) Physical oceanography of the Gulf of Maine. Bull US Bur Fish 40 (2):511-1027

Blumberg AF, Mellor GL (1987) A description of a threedimensional coastal ocean circulation model. In: Heaps NS (ed) Three-dimensional coastal ocean models; Coastal and estuarine sciences, Vol 4. American Geophysical Union, Washington, DC, p 1-6

CETAP (Cetacean and Turtle Assessment Program) (1982) A characterization of marine mammals and turtles in the Mid- and North-Atlantic areas of the US outer continental shelf, Final report. Contract No. AA551-CT8-48. Bureau of Land Management, US Department of the Interior, Washington, DC

Conversi A, Piontkovski S, Hameed S (2001) Seasonal and interannual dynamics of Calanus finmarchicus in the Gulf of Maine (Northeastern US shelf) with reference to the North Atlantic Oscillation. Deep-Sea Res II 48:519-530

Dickson R, Lazier J, Meincke J, Rhines P, Swift J (1996) Longterm coordinated changes in the convective activity of the North Atlantic. Prog Oceanogr 38:241-295

Durbin EG, Campell RG, Gilman SL, Durbin AG (1995a) Diel feeding behavior and ingestion rate in the copepod Calanus finmarchicus in the southern Gulf of Maine during late spring. Cont Shelf Res 15:539-570

Durbin EG, Gilman SL, Campell RG, Durbin AG (1995b) Abundance, biomass, vertical migration and estimated development rate of the copepod Calanus finmarchicus in the southern Gulf of Maine during late spring. Cont Shelf Res 15:571-591

Epstein AW, Beardsley RC (2001) Flow-induced aggregation of plankton at a front: a 2-D Eulerian model study. DeepSea Res 48:395-418

Folt CL, Burns CW (1999) Biological drivers of zooplankton patchiness. Trends Ecol Evol 14:300-305

Franks PJS (1992) Sink or swim: accumulation of biomass at fronts. Mar Ecol Prog Ser 82:1-12

Geyer RW, Gardner G, Brown W, Irish J, Butman B, Loder T, Signell R (1992) Physical oceanographic investigation of Massachusetts and Cape Cod Bays. Report to the Massachusetts Bays Program, MBP-92-03, Boston, MA

Greene CH, Pershing AJ (2000) The response of Calanus finmarchicus populations to climate variability in the Northwest Atlantic: basin-scale forcing associated with the North Atlantic Oscillation. ICES J Mar Sci 57:1536-1544

Greene CH, Pershing AJ, Conversi A, Planque B and 10 others (2003) Trans-Atlantic responses of Calanus finmarchicus populations to basin-scale forcing associated with the North Atlantic Oscillation. Prog Oceanogr 58:301-312

Hendry R, He I (1996) Technical report on objective analysis 
(OA) project. Bedford Institute of Oceanography, Dartmouth, Nova Scotia

Hunter JR, Craig PD, Philips HE (1993) On the use of random walk models with spatially variable diffusivity. J Comput Phys 106:366-376

Jiang MS, Zhou M (2004) The summer Ekman pumping and its implications to the deep water renewal in Massachusetts and Cape Cod Bays. Estuarine Coastal Modeling: Proc 8th Int Conf, San Francisco, CA, p 929-948

Jiang MS, Wallace GT, Zhou M, Libby S, Hunt C (2007a) Summer formation of a high nutrient and low oxygen pool in Cape Cod Bay, USA. J Geophys Res 112:C05006, doi: 10.1029/2006JC003889

Jiang MS, Zhou M, Libby S, Hunt C (2007b) Influences of GOM intrusion on the Massachusetts Bay spring bloom. Cont Shelf Res (in press)

Keller AA, Taylor C, Oviatt C, Dorrington T, Holcombe G, Reed L (2001) Phytoplankton production patterns in Massachusetts Bay and the absence of the 1998 winter-spring bloom. Mar Biol 138:1051-1062

Kenney RD, Winn HE (1986) Cetacean high-use habitats of the northeast United States continental shelf. Fish Bull 84(2):345-357

Kenney RD, Winn HE, Macaulay MC (1995) Cetaceans in the Great South Channel, 1979-1989: right whale (Eubalaena glacialis). Cont Shelf Res 15:385-414

Kenney RD, Mayo CA, Winn HE (2001) Migration and foraging strategies at varying spatial scales in western North Atlantic right whales: a review of hypotheses. J Cetacean Res Manage (Special Issue) 2:251-260

Kraus SD, Moore KE, Price CA, Crone MJ, Watkins WA, Winn HE, Prescott JH (1986) The use of photographs to identify individual North Atlantic right whales (Eubalaena glacialis). Rep Int Whal Commn (Special Issue) 10: 145-151

Large WG, Pond S (1981) Open ocean momentum flux measurements in moderate to strong winds. J Phys Oceanogr 11:324-336

Loder JW, Shen Y, Ridderinkhof H (1997) Characterization of three-dimensional Lagrangian circulation associated with tidal rectification over a submarine bank. J Phys Oceanogr 27:1729-1742

Longuet-Higgins MS (1969) On the transport of mass by timevarying ocean currents. Deep-Sea Res 16:431-447

Editorial responsibility: Otto Kinne (Editor-in-Chief), Oldendorf/Luhe, Germany
Mayo CA, Marx MK (1990) Surface foraging behaviour of the North Atlantic right whale, Eubalaena glacialis, and associated zooplankton characteristics. Can J Zool 68: $2214-2220$

Mayo CA, Nichols OC, Bessinger MK, Brown MW, Marx MK, Browning CL (2004) Surveillance, monitoring, and management of North Atlantic right whales in Cape Cod Bay and adjacent waters-2004. Final report submitted to the Commonwealth of Massachusetts, Division of Marine Fisheries. Center for Coastal Studies, Provincetown, MA

Murison LD, Gaskin DE (1989) The distribution of right whales and zooplankton in the Bay of Fundy, Canada. Can J Zool 67:1411-1420

Ottino JM (1989) The kinetics of mixing: stretching, chaos, and transport. Cambridge University Press, Cambridge

Petrie B, Drinkwater K (1993) Temperature and salinity variability on the Scotian Shelf and in the Gulf of Maine 1945-1990. J Geophys Res 98(C11):20,079-089

Ridderinkhof H, Loder JW (1994) Lagrangian characterization of circulation over submarine banks with application to the outer Gulf of Maine. J Phys Oceanogr 24:1184-1200

Scott GP, Gilbert JR (1982) Problems and progress in the U.S. BLM-sponsored CETAP surveys. Rep Int Whal Commn 32: 587-600

Signell RP, Jenter HL, Blumberg AF (2000) Predicting the physical effects of relocating Boston's sewage outfall. Estuar Coast Shelf Sci 50:59-72

Thomas AC, Townsend DW, Weatherbee R (2003) Satellitemeasured phytoplankton variability in the Gulf of Maine. Cont Shelf Res 23:971-989

Turner JT, Borkman DG, Hunt CD (2006) Zooplankton of Massachusetts Bay, USA, 1992-2003: relationships between the copepod Calanus finmarchicus and the North Atlantic Oscillation. Mar Ecol Prog Ser 311:115-224

Weller R, Rudnick D, Brink NJ (1995) Meteorological variability and air-sea fluxes at a closely spaced array of surface moorings. J Geophys Res 100:4867-4883

Winn HE, Price CA, Sorensen PW (1986) Distributional biology of the right whale in the western North Atlantic. Rep Int Whal Commn (Special Issue) 10:129-138

Zimmermann JTF (1981) Dynamics, diffusion and geomorphological significance of tidal residual eddies. Nature 290:549-555

Submitted: October 2, 2006; Accepted: June 7, 2007

Proofs received from author(s): October 16, 2007 